\title{
Climate Change and Infections on the Move in North America
}

\author{
Naomi Hauser $\mathbb{D}^{1,2}$ \\ Kathryn C Conlon ${ }^{2-4}$ \\ Angel Desai' \\ Leda N Kobziar ${ }^{5}$ \\ 'Department of Medicine, Division of \\ Infectious Disease, University of \\ California Davis Health, Sacramento, CA, \\ USA; ${ }^{2}$ Climate Adaptation Research \\ Center, University of California, Davis, \\ CA, USA; ${ }^{3}$ Department of Public Health \\ Sciences, School of Medicine, University \\ of California Davis, Davis, CA, USA; \\ ${ }^{4}$ Department of Veterinary Medicine \& \\ Epidemiology, School of Veterinary \\ Medicine, University of California Davis, \\ Davis, CA, USA; ${ }^{5}$ Department of Natural \\ Resources and Society, University of \\ Idaho, Coeur d'Alene, ID, USA
}

\begin{abstract}
Climate change is increasingly recognized for its impacts on human health, including how biotic and abiotic factors are driving shifts in infectious disease. Changes in ecological conditions and processes due to temperature and precipitation fluctuations and intensified disturbance regimes are affecting infectious pathogen transmission, habitat, hosts, and the characteristics of pathogens themselves. Understanding the relationships between climate change and infectious diseases can help clinicians broaden the scope of differential diagnoses when interviewing, diagnosing, and treating patients presenting with infections lacking obvious agents or transmission pathways. Here, we highlight key examples of how the mechanisms of climate change affect infectious diseases associated with water, fire, land, insects, and human transmission pathways in the hope of expanding the analytical framework for infectious disease diagnoses. Increased awareness of these relationships can help prepare both clinical physicians and epidemiologists for continued impacts of climate change on infectious disease in the future.
\end{abstract}

Keywords: climate change, global warming, infectious disease, environment, antimicrobial resistance

\section{Introduction}

Climate change is directly and indirectly impacting human health now. ${ }^{1,2}$ The impacts will continue along this trajectory, in most development and emission scenarios, growing in scope and scale, without substantial elimination of the root cause of the climate crisis: the emission of greenhouse gas pollutants. ${ }^{2-7}$ Despite the inherent threats that the climate crisis poses to human health, it has been a relatively recent trend that explicit attention has been paid to the risks a changing climate has on human health. ${ }^{8}$ For instance, in 1990 when the first Intergovernmental Panel on Climate Change's (IPCC) report was released, "health" was mentioned throughout but not given the profound consideration that modern assessment reports now give climate and health. Since that initial publication, subsequent assessments and reports have increasingly dedicated space to specific human health content areas. $^{1,2,8,9}$ In addition to expected climate-driven hazards such as extreme events like prolonged high temperatures (ie, heat waves), tropical cyclones, droughts, and flooding, the scope of these assessments has expanded into health-related areas like infectious and non-infectious diseases, occupational health, mental health, human migration, and malnutrition. ${ }^{2,5,9-15}$ This is, in part, due to an exploding research field that has identified and characterized the myriad ways climate change impacts health.
Correspondence: Naomi Hauser Department of Medicine, Division of Infectious Disease, University of California Davis Health, 4I50 V St, PSSB G500, Sacramento, CA, 958I7, USA

Tel + I 916-734-8516

Fax + I 916-734-7766

Email nehauser@ucdavis.edu 
Morbidity and mortality can be directly associated with extreme temperatures, ${ }^{2,16-19}$ tropical and coastal storms, ${ }^{20-23}$ and wildfires. ${ }^{2-26}$ Yet, how weather and climate impact health is complex: the effects are not always direct, instead following numerous indirect pathways. Social, contextual, and individual characteristics contribute to a person's risk of death or disease. For instance, during an extreme heat event, a person with underlying health conditions (eg, asthma, COPD) may experience increased complications during infrastructure failures (eg, power outages). ${ }^{27}$ In February 2021, winter snow storms caused delayed delivery of health-care supplies across the country, including nearly one million COVID-19 vaccine doses, 730,000 of them going to Texas, alone. ${ }^{28}$

While climate change will affect human populations across the globe, the impacts will vary considerably, multiplying existing threats related to equity, justice, diversity, and inclusion. ${ }^{29}$
Climate change-related health impacts include allergies, pregnancy and newborn complications, heart and lung disease, risks for children, dehydration and kidney problems, heat stroke, skin disease, digestive illnesses, mental health conditions, neurologic disease, nutrition, trauma, and infectious diseases. While all are important, the relationship between climate change and infectious disease is particularly compelling as it is determined by the integration of the biosphere and the human realm. Knowledge of both ecological and human health sciences is needed to understand and project how and why infectious diseases are "on the move" in response to climate change. The mechanisms by which climate change impacts infectious disease are diverse and often overlapping, including ecological, social, and biological factors (Figure 1). Infectious disease transmission is influenced by local temperatures, extreme weather events, and

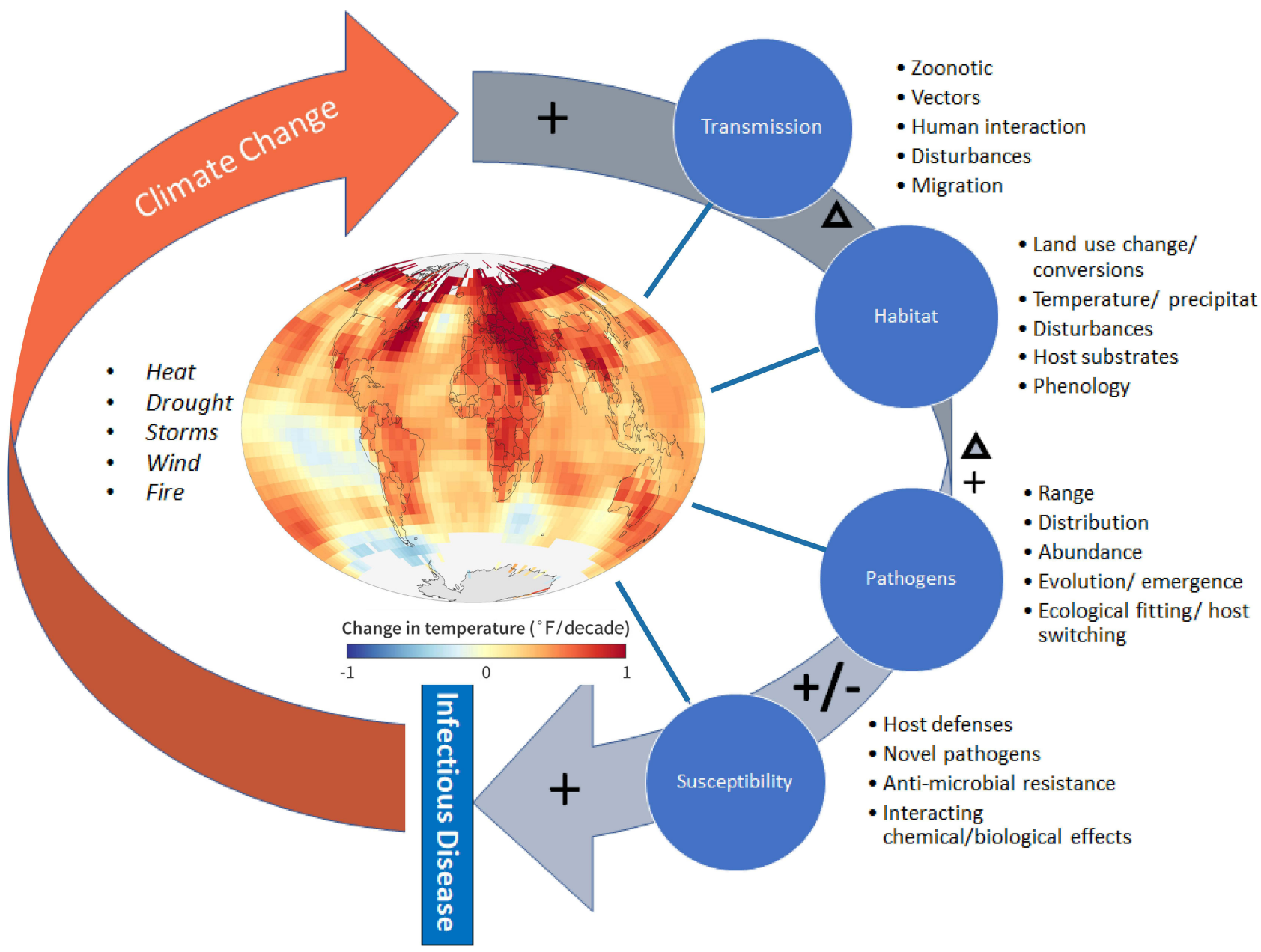

Figure I Conceptual diagram depicting four major infectious disease factors affected by global warming and climate change: transmission and dispersal of pathogens, pathogen habitat, pathogen evolution and distribution, and susceptibility of hosts. Generalized directions of change (increase, decrease, or multi-directional change) resulting from climate change for each factor are indicated by symbols. Examples of how each of the factors are affected by climate change related heating, drought, storms, wind, and fire are provided. Map from NOAA Climate.gov map, based on data from NOAA Centers for Environmental Information. Available from https://www.climate.gov/media/ 12884. The re-use of Climate.gov content should not imply NOAA endorsement of a product, service, or organization. ${ }^{127}$ 
exposure to animal and insect vectors, as well as increasing interactions between people due to climate and weather-driven displacement, migration, and rising population densities around limited natural resources. Climate change also influences the habitat for infectious diseases by impacting land use and both terrestrial and aquatic ecosystem characteristics in environmental reservoirs (eg, changes in temperature and moisture regimes) ${ }^{30}$ increasing disturbances and associated changes in host substrate availability, and alterations to the timing and seasonality of the lifecycles of infectious organisms as well as their hosts. Direct impacts on pathogen populations are evidenced in increasing abundances and expanded ranges, the emergence of novel species and strains, ${ }^{31}$ and associated host switching or broadening. ${ }^{32}$ Finally, susceptibility of humans to infectious disease is impacted by climate change due to impacts on resources (eg, clean water and air, high-quality nutrition, shelter) and how these affect host defense systems, anti-microbial resistance of some strains of pathogens, and novel, emerging pathogens. ${ }^{32,33}$ A summary of the infectious diseases mentioned in this review and their relationship to climate change and extreme weather is presented in Table 1.

\section{Climate Change Primer}

While the average global temperature is rising, the amount of warming is not distributed equally. Because of the heat capacity of water, the ocean functions effectively as a heat sink, and air above the ocean warms more slowly than air above land, which means that land-locked areas are expected to experience more drastic warming than coastal areas. High latitude areas are experiencing warming more quickly than the equator, leaving the Arctic to warm about twice as fast and the Antarctic Peninsula to warm about five times as fast as the global average. ${ }^{34}$ High altitude regions also experience global warming at a faster rate than sea level regions due to changes in humidity and solar energy. ${ }^{35}$

A warming climate also has effects on weather and extreme weather events such as wildfires, drought, and coastal storms. Warmer temperatures can enhance water evaporation from soil and other organic matter and can increase the water demand of vegetation leading to worsening droughts and wildfires. Drier soils and high wind events can mobilize pathogens from soil environmental reservoirs. Warmer sea surface temperatures and sea level rise can intensify coastal storms. ${ }^{36-38}$ Extreme

Table I Several Human Pathogens, Their Mode of Transmission, Reported or Suspected Association to Climate Change or Its Consequences, and Representative References

\begin{tabular}{|c|c|c|c|}
\hline Pathogen & Mode of Transmission & Climate-related event & References \\
\hline Vibrio species & Water & $\begin{array}{l}\text { Warming water } \\
\text { temperatures }\end{array}$ & $\begin{array}{l}\text { Randa et al 2004; Logar-Henderson et al 2019; Weis et al 20I I; } \\
\text { Newton et al 2012; Jones et al } 2013\end{array}$ \\
\hline Naegleria fowleri & Water & $\begin{array}{l}\text { Warming water } \\
\text { temperatures }\end{array}$ & Capewell et al 2015; Gharpure et al 202I \\
\hline $\begin{array}{l}\text { Leptospira } \\
\text { interrogans }\end{array}$ & Water & Floods & $\begin{array}{l}\text { Gaynor et al 2007; Togami et al 20I2; Amilasan et al 2009; Lau et } \\
\text { al } 2010\end{array}$ \\
\hline Fusarium species & Soil & Warming air temperatures & Timmusk et al 2020; Wurster et al 2020 \\
\hline Cryptococcus gattii & Soil & $\begin{array}{l}\text { Warming air and } \\
\text { soil temperatures }\end{array}$ & $\begin{array}{l}\text { Kidd et al 2007; CDC MMWR 20I0; Rosas and Casadevall I997; } \\
\text { Want and Casadevall 1994; Schiave et al } 2009\end{array}$ \\
\hline Various moulds & Air & Wildfire smoke & Kobziar et al 20I8; Moore et al 202I; Mulliken et al 2019 \\
\hline Coccidioides & Air & Wildfire smoke & $\begin{array}{l}\text { Kobziar and Thompson 2020; Kobziar et al 2018; Elbert et al } \\
2007\end{array}$ \\
\hline Borrelia burgdorferi & Tick vector & $\begin{array}{l}\text { Wildfire/burn events, } \\
\text { warming air temperatures }\end{array}$ & $\begin{array}{l}\text { Ogden and Lindsay 2016; Ogden et al 2014; Leighton et al 2012; } \\
\text { Simon et al 2014; Rounsville 202I }\end{array}$ \\
\hline Norovirus & Person-to-person & Human displacement & Yee et al 2007 \\
\hline HIV & Person-to-person & Human displacement & Nsuami et al 2009; Ekperi et al 2018 \\
\hline
\end{tabular}


weather events are often categorized by monetary losses and the most notable events are those that make the "billion-dollar extreme weather events" list. ${ }^{39}$ From 1980 to now there have been almost 300 individual billion-dollar weather disasters in the US, with 22 events in 2020 alone, including the record-breaking wildfire season that burned over 10M acres of land in California, more than twice as much land as the previous record set in $2018 .{ }^{39}$ Climate change itself and the resulting extreme weather events have both direct and indirect effects on human health such as heatstroke, dehydration, asthma, cardiac events, and changes in pathogen exposure. ${ }^{1}$ Here, we highlight key examples of how these mechanisms of climate change affect the present and future infectious diseases associated with water, fire, land, insects, and human transmission pathways.

\section{Water}

Changes in water temperature, salinity, currents, and seasonality patterns are all results of climate warming that can affect the abundance and incidence of water-borne infections. Such infections can cause a range of diseases associated with ingestion, inhalation, or direct inoculation of pathogens. For example, climate models indicate that sea surface temperature increases will track with an increase in the abundance, geographic distribution, and duration of risk of Vibrio species infections, some of which have a mortality rate of up to $50 \%{ }^{40-43}$ Infections with pathogenic Vibrio species, including $V$. cholerae, the bacterium responsible for the diarrheal disease, cholera, have been well-studied and infections have been linked to climate change and extreme weather events. ${ }^{44,45}$ While all Vibrio species can cause severe illness resulting from a gastrointestinal infection via ingestion or wound infection via direct inoculation, different species have varying degrees of disease association. $V$. cholerae is best known for its association with profuse watery diarrhea, while V. vulnificus is more often associated with wound infections. ${ }^{46}$ In the US, the non-cholera Vibrio species V. parahaemolyticus, vulnificus, and alginolyticus are responsible for the largest disease burden among Vibrio species. ${ }^{47}$ Altogether, Vibrio infections account for approximately 80,000 illnesses and are estimated to cost about $\$ 300$ million annually in the U.S. ${ }^{48}$

The prevalence of Vibrio species is regional and dynamic. Most species naturally occur in coastal and estuarine water where the environment is warm and brackish, with seasonal variations in prevalence and infection risk. ${ }^{44,49}$ Gulf Coast, Mid-Atlantic, and Northeastern states, along with Washington and Hawaii, have the highest reported incidence of vibriosis (ie, non-cholera Vibrio infection) in the U.S. ${ }^{50}$ An analysis of C.D.C. Vibrio surveillance data found a 15 -year increase in vibriosis incidence nationwide for all three of the most common non-cholera Vibrio species from 1996 to 2015, a trend that has been associated with warming ocean temperatures. ${ }^{50}$ Warming sea surface temperatures have also been associated with increased incidence of $V$. vulnificus, the most fatal Vibrio species with a fatality rate of up to $50 \%$, in coastal locations - notably Florida and Maryland. ${ }^{49,51}$ Studies have also found a longer V. vulnificus and parahaemolyticus detection period with prolonged water temperature warming, as well as broader salinity tolerance with higher temperatures. ${ }^{43,44}$ The geographic distribution of cases of primary amebic meningoencephalitis (P.A.M.) also appears to have expanded due to increasing average annual water temperatures. P.A.M. is a rare brain infection with roughly eight cases reported in the US annually. It is primarily a pediatric illness and has a fatality rate of greater than $97 \% .{ }^{52,53}$ P.A.M. is caused by an infection with the free-living amoeba Naegleria fowleri, which is found in soil and warm freshwater, and infection is most often associated with exposure to natural recreational water such as lakes or ponds. ${ }^{54}$ Historically, exposures in the US have occurred in the southern states, but in recent years the geographic range seems to have been expanding northward. ${ }^{53,54}$ A 2013 C.D.C. review of P.A.M. in the US from 1937-2013 found that of the 142 cases across 18 states, the majority have been identified in the southern half of the country, primarily Texas, Florida, and Virginia; cases have been diagnosed as far north as Minnesota, however, with the four northernmost cases over the 76-year timespan all identified in or after $2010 .{ }^{53}$ This finding was confirmed in a second review of P.A.M. cases in the US from 1978-2018 which found 120 reported cases over the 40-year timespan, 85 of whom had a clear known or suspected single exposure. ${ }^{54}$ Five of the six Midwestern cases occurred after $2010 .^{54}$ The authors also performed a temperature analysis and found a significantly higher daily average temperature in the two weeks before exposure compared to the previous 20 years, and a shift in the maximum latitude of cases equivalent to $13.3 \mathrm{~km}$ northward each year. $^{54}$

As evidence of the links between warming water bodies and water-borne pathogens increases, an increase in infectious diseases and extreme precipitation events has also been observed. Leptospira interrogans is a spirochetal bacterium spread through contact with the urine of 
infected animals that causes the clinical syndrome leptospirosis in humans. Manifestations of disease can range from asymptomatic infection to a flu-like syndrome with fevers, chills, and muscle aches to a more severe illness resulting in multiorgan failure. ${ }^{55-57}$ In 2004 , heavy rains caused flooding on the University of Hawaii campus in Honolulu which left indoor standing water in affected buildings for several days after normal campus activities resumed. Laboratory testing and epidemiological surveys confirmed leptospirosis infection in two people whose only exposure was a flooded campus laboratory. ${ }^{58}$ About 100-200 cases of leptospirosis are reported within the US each year and about half of annual cases occur in Hawaii. ${ }^{59}$ A 1997 case study of leptospirosis in Hawaii reported a range of zero to four cases in Oahu per year from 1986 to 1992 associated with either farming or recreational swimming. ${ }^{60}$ As climate change leads to a combination of rising ocean levels and extreme precipitation events, floods will increase in both rural and urban areas, also increasing the risk of human infection from exposure to contaminated water. ${ }^{58,61-63}$

\section{Soil and Plant Biota}

Several soil- and plant-dwelling pathogenic microbial species with human and food-related infectious disease impacts are expected to increase in range and virulence in response to climate change. For example, outbreaks of Fusarium crop infections have occurred largely with warmer weather conditions and are expected to increase with an overall warming climate. ${ }^{64}$ Fusarium species, which make up a large group of plant and animal pathogens, ${ }^{64,65}$ produce mycotoxins which can contaminate food crops leading to deadly human health consequences including acute toxic effects as well as various cancers. ${ }^{64,66,67}$ Climate change-induced increases in storm frequency and severity may impact other common pathogenic microbes in surprising ways: Mucorales molds undergoing shear stresses experienced in tornadoes or cyclones have increased virulence, which suggests that storms do more than enhance the distribution of pathogenic organisms. ${ }^{67}$ Clusters of necrotizing myocutaneous mucormycosis with high mortality rates have been evidenced in relation to high-energy events around the world. ${ }^{64,67}$

Cryptococcus gattii, a human pathogenic yeast with wood and soil as environmental reservoirs, is found in various geographic locations, but with the highest incidence in Vancouver Island, Canada, where it was first identified in $1999 .{ }^{68-70} \mathrm{C}$. gattii is acquired via inhalation of spores causing some degree of pulmonary infection in about half of exposed patients. From the lungs, the infection can disseminate to other sites, most commonly the central nervous system where it can cause a potentially fatal meningitis in both immunocompromised and immunocompetent individuals. ${ }^{71} C$. gattii has been found to thrive in sunny areas of moderate temperature with abovefreezing winters, such as Vancouver Island where $7.7 \%$ of tree samples, $9.6 \%$ of soil samples, and $27 \%$ of air samples are positive for the fungus. ${ }^{72} \mathrm{C}$. gattii has been isolated from tree, soil, and air samples further south along the west coast of North America in Washington and Oregon at lower prevalence, and infections have been identified in the additional western states of California and Idaho. ${ }^{72,73}$ Cryptococcus and other fungi produce melanin in response to environmental stress, and melanization of $C$. neoformans has been associated with increased temperature tolerance to both heat and cold, although its relationship to ultraviolet light tolerance has been mixed. ${ }^{74-76}$ After a 2010 outbreak of C. gattii in Oregon, the investigators noted the broader geographic range than previously identified, indicating the possibility of the organism's adaptation to new climates or that a changing climate may be responsible for creating a wider hospitable habitat. ${ }^{73}$

Some have speculated that novel, emerging infectious agents with high temperature tolerance and resistance to anti-fungal therapy, such as Candida auris, may be the result of a combined influence of climate-related changes in the environment coupled with increased human contact. ${ }^{77}$ There is now evidence that environmental microbes genetically evolve under environmental pressure along with potentially increasing in prevalence and geographic distribution. ${ }^{78}$ As a proof of concept, a recent study assessed the evolution of the soil bacterium genus Curtobacterium in response to new but natural environments and climates including changes in microbial and other biotic composition, temperature, and precipitation. $^{78}$ After only 18 months, shifts were seen in the abundance of both the overall microbial community composition and the isolated Curtobacterium population in response to the environmental changes. Additionally, over the same period, phenotypic changes were seen in Curtobacterium communities reflecting adaptation to new and varying environments, and genotypic changes occurred even more quickly. Although Curtobacterium is not a known human pathogen, its rapid evolution may 
have implications for other soil microbes that do cause human disease.

\section{Air}

As climate change leads to warming global average temperatures, longer fire seasons, and longer durations of drought, it increases the potential for larger and more severe wildfires especially in regions like the western U.S. ${ }^{79,80}$ A 2020 special report in The New England Journal of Medicine highlighted the human health effects of climate change and wildfires, with emphasis on direct burn injury, smoke particulate matter inhalation, and mental health effects. ${ }^{24}$ Notably missing from the report, however, were the potential infectious disease complications of worsening wildfires from either direct burn injuries followed by secondary infections, or from smoke and microbial inhalation. ${ }^{24,81}$ Patient factors such as immune state, surface area and depth of burns, and severity of illness play a large role in the risk of infection and susceptibility to various organisms in burn patients. ${ }^{82-87}$ There is also increasing interest in the potential ecological changes associated with wildfires that may play a role in human pathogen exposure and infection, especially where severe forest fires are followed by extreme precipitation events and flooding.

A new area of research (pyroaerobiology) now focuses on the living components of smoke which are, at least in part, made up of infectious pathogens of concern for human and/or crop health. ${ }^{87}$ In recently published studies, researchers from the University of Idaho and the University of Florida analyzed microbial cells in smoke emitted from prescribed fires in North Florida and found that smoke contained fivefold higher concentrations of microbial cells with increased bacterial and fungal species richness than the pre-ignition air. ${ }^{87,88}$ The type of fuel burned (eg, different plant or tree species, organic soils) also influenced the concentration and diversity of mobilized bioaerosols. ${ }^{87}$ The authors further distinguished between viable and non-viable DNA-containing cells and found that approximately $80 \%$ of the cells in smoke were viable. Across multiple studies, numerous potential plant and human pathogens or allergens were identified in wildland fire smoke but not in paired background air conditions, including Cryptococcus spp., Aspergillus spp., Sarocladium spp., Candida spp., Pseudomonas syringae, Cladophialophora spp., Ochroconis spp., Bacillus anthracis-cereus, and Mucor spp., among others. ${ }^{89}$
Researchers anecdotally noted more invasive fungal infections after a large wildfire in California, US in 2017, leading them to ask whether wildfire or smoke exposure could be associated with an increased risk of invasive fungal infections such as aspergillosis and coccidioidomycosis. To investigate, they collected data from 22 California hospitals over four years and compared admissions for invasive mold infections with the occurrence of large wildfires within a 200-mile radius of the admitting hospital. Large fires characterized nearly half of the study months and were associated with an increased risk of admission for invasive mold infections, aspergillosis, and coccidioidomycosis, but not invasive Candida infection which served as the control. ${ }^{88}$ This study does not take into account the potential confounding or multiplicative effects of seasonal dust and wind storms which may also influence transport and human intersection with infectious disease, but serves as a unique example of such a comparison between wildfire occurrence and fungal infection admission rates and warrants further study.

During the 2017 wildfire season, a group of incarcerated individuals working as wildland firefighters were identified by the California Department of Public Health as cases in a coccidioidomycosis cluster. Ten cases (four clinical and six lab-confirmed) were reported among the 198 firefighters who worked on the case study wildfire, and illness was associated with patients who experienced a dust storm or more frequently worked on constructing fire lines, both of which disturb soils and can mobilize fungal Coccidioides spores. None of the study participants reported wearing respiratory protection. It is unclear whether the cases were the result of inhaling smoke containing organisms mobilized during combustion (which can aerosolize mineral and organic soils), or from simply disturbing the soil during line construction. Importantly, respiratory coverings are uncommon personal protective equipment among wildland firefighters. ${ }^{90}$ Authors suggest that increasingly severe wildfire seasons may increase both human and animal exposure to pathogens from soils or partially combusted vegetation that are transported by smoke. $^{80,86}$

The epidemiological, experimental, and anecdotal data indicate the possibility of an association between wildfires and invasive fungal infections, and there is also evidence that suggests that wildfire patients may be at increased risk of certain post-burn bacterial infections as well. ${ }^{91}$ Sherry et al ${ }^{91}$ compared bacterial culture data in wildfire burn patients to routine burn patients to assess 
differences in bacterial colonization. Among the 18 wildfire burn patients and 36 routine burn patients included in the study, wildfire burn patients had significantly more cultures resulting in bacterial growth overall and more Gram negative bacteria cultured from wounds. ${ }^{91}$ These findings suggest the possibility that environmental exposures may increase the risk of infection with certain environmental pathogens while simultaneously contributing to the alteration of the human microbiome.

\section{Insect Vectors}

Anthropogenic climate change and extreme weather events have the potential to alter the habitats and geographic distribution of large numbers of animals, including hosts and vectors of human infectious diseases.

The US is home to many tick vectors with the potential to carry and spread a variety of infectious pathogens. Lyme disease is the most prevalent vector-borne disease in the US and is endemic to the Northeast and Midwest. It is caused by the bacterium Borrelia burgdorferi, transmitted to humans by the Ixodes genera of ticks, primarily I. scapularis in the US and Canada, with a much smaller contribution from I. pacificus. ${ }^{92}$ These ticks acquire the B. burgdorferi pathogen after feeding on a reservoir host, commonly the white-footed mouse. ${ }^{93}$ Early stages of Lyme disease can manifest as a well-defined rash, or, if left untreated, can develop into more serious consequences such as arthritis, meningitis, and cardiac arrhythmias. ${ }^{92}$

A changing geographic distribution of Ixodes tick species also appears to be linked to climate warming, in general, in North America. ${ }^{94,95}$ While Lyme disease was first identified in the US in the 1970s, it was not identified in Canada until around 2004 and northward expansion of the Ixodes tick continues. ${ }^{94,95}$ Empirical models of Ixodes distribution in Canada have found that not only will the geographic distribution of the tick vector expand with a warming climate, but the rate of expansion also increases as temperatures warm. ${ }^{96}$ One of the primary reasons for this geographic expansion is the increasing reproductive capacity of ticks that is associated with warmer temperatures and seems to be independent of other factors such as host abundance, rainfall, and tick migration. ${ }^{95}$ The geographic distribution of the white-footed mouse, frequently the most important reservoir host of B. burgdorferi, however, is also predicted to expand in both northern and southern directions with a warming climate. ${ }^{97}$ Currently, the white-footed mouse geographic distribution appears to be expanding at a rate of about $10-15 \mathrm{~km}$ per year in parts of the Midwestern US and Canada, most closely associated with shortened winters. ${ }^{98}$ The expansion of both the primary reservoir host and insect vector of B. burgdorferi have serious and compounding implications for the increasing risk of Lyme disease in North America. $^{99}$

A variety of other ticks are known to transmit human infection in North America, including the Dermacentor variabilis tick. This species is widely distributed across the United States and Southern Canada and transmits the rickettsial organism, Rickettsia rickettsii, the agent of Rocky Mountain Spotted Fever (RMSF), a potentially fatal disease. ${ }^{100}$ A 2020 study aimed to characterize the tick, reservoir host, and pathogen communities over a twoyear period following a large 2015 wildfire. ${ }^{101}$ Ticks were collected from rodents before and after a wildfire at burned (Stebbins Cold Canyon Natural Reserve) and nearby unburned (Quail Ridge Natural Reserve) sites about $6.5 \mathrm{~km}$ apart in Northern California. All ticks were of either the Ixodes (five species) or Dermacentor (two species) genera. Interestingly, the study found a significant shift in tick genera proportions from predominantly Ixodes spp to more equal proportions of Ixodes and Dermacentor spp at both sites pre- and post-fire: at the Cold Canyon burned site, $100 \%$ of the ticks pre-fire were of the Ixodes genus, which shifted to $55.81 \%$ Ixodes and $44.19 \%$ Dermacentor post-fire; at the Quail Ridge unburned site, $87.5 \%$ of the ticks pre-fire were of the Ixodes genus and $12.5 \%$ were of the Dermacentor genus, which shifted to $31.25 \%$ Ixodes and $68.75 \%$ Dermacentor post-fire. ${ }^{101}$ The authors also found a significant increase in the number of animals infested with ticks at both sites when considered together, which was primarily driven by an increase at the unburned Quail Ridge site from 9.9\% pre-fire to $48 \%$ postfire. ${ }^{101}$ Additionally, a longer duration of infestation was seen at the unburned site where animals were only infested during the Spring and Summer pre-fire but through all four seasons post-fire. ${ }^{101}$ The number of small mammal species more than tripled from pre- to post-fire at the burned site, while near doubling from pre- to post-fire at the unburned site. These findings suggest that wildland fires alter host and vector habitats and prevalence of disease-carrying ticks by increasing abundance of the host reservoir. ${ }^{101}$

Several mosquito-borne diseases are also apparent in North America and include West Nile, Chikungunya, and Zika viruses. Local Chikungunya transmission was first identified in the Americas in 2013, and over the next two years spread through 45 countries throughout North and 
South America, affecting a suspected 1.7 million people. ${ }^{102}$ Similarly, local Zika virus transmission was first confirmed in Brazil in 2015 and by the following year local transmission was being reported in multiple countries in North and Central America. ${ }^{102}$ West Nile virus, now the most common mosquito-borne disease in the US, was not identified in the US until 1999 in New York City. ${ }^{103}$ By 2012, the virus had spread throughout the entire continental U.S. ${ }^{103}$ The initial mode of introduction to N.Y.C. remains unclear. Studies have shown positive relationships between warming ambient temperature and the potential for West Nile virus infection via factors such as increased viral replication, vector growth rates, and viral transmission to animal hosts, which will only worsen as global temperatures continue to rise. ${ }^{103}$ In the context of the current pandemic, it is increasingly important to recognize and continue to study links between climate change and zoonotic and vectorborne diseases in order to begin to predict and, hopefully, prevent future outbreaks.

\section{Population Displacement}

In 2019, 33.4M people were displaced around the world, $23.9 \mathrm{M}$ of whom were displaced by weather-related events. ${ }^{104}$ Changing climate and extreme weather events have been implicated as critical drivers of large-scale human population movement, though the relationship between climate change and migration remains highly debated. ${ }^{105-107}$ Although environmental migration, or the temporary or permanent movement of people due to changes in the environment, is a recognized phenomenon, extreme weather events are increasingly considered to be exacerbating factors of global human displacement. ${ }^{108-110}$ While weather events such as floods, hurricanes, and fires have historically been associated with temporary displacement, as these events continue to increase in frequency, longer lasting environmental change may necessitate permanent relocation for vulnerable communities. ${ }^{111}$ In North America, for example, droughts and famines related to climate change and extreme weather events such as El Nino have been associated with increasing northward migration from Central America. ${ }^{111-113}$ Despite these concerns, individuals displaced due to extreme weather events are not designated as refugees under international law, given uncertainties surrounding classification, characterization, and duration of displacement. ${ }^{114}$

The long-term health impacts of displacement due to climate and extreme weather events remain to be seen, and data investigating these phenomena remain sparse. Existing literature has suggested that extremes in temperature and frequency of natural disasters may be associated with food insecurity and changes in infectious disease epidemiology. ${ }^{105,115}$ Displacement in the setting of extreme weather events and subsequent infectious disease outcomes is less well understood, though overcrowding in shelters or camps used to house individuals who have been displaced may be associated with subsequent communicable disease outbreaks. For example, following Hurricane Katrina in 2005, 27,000 people displaced by the event were evacuated to a single center in Houston, Texas. Within two weeks, over 1000 people presented to the shelter clinic with symptoms of gastroenteritis. Additionally, multiple strains of Norovirus, a highly transmissible gastrointestinal infection, were identified in nearly half of the people who submitted samples for analysis. ${ }^{116}$ Public health investigators hypothesized that overcrowding and lack of adequate hygiene and sanitation facilities may have exacerbated the spread of infection. ${ }^{116}$

Apart from overcrowding, delayed or missed diagnosis due to changing infectious disease epidemiology, missed routine childhood vaccinations in the setting of unexpected displacement, and increasing population exposure at the human-animal interface represent other potential routes of communicable disease transmission in the setting of extreme weather events and climate change. ${ }^{105,111,117}$ Given these challenges, adapting public health surveillance and infrastructure to meet the needs of populations displaced by climate change-driven natural disasters will be paramount, and additional research in this area is needed.

\section{Antimicrobial Resistance and Climate Change}

Not only does climate change have the potential to increase the risk of human exposure to various infectious agents, there is evidence linking a changing climate to increasing difficulty in treating infections due to increased antimicrobial resistance. ${ }^{18-120}$ Antibiotics used in aquaculture are among the same classes used in people and animals, and leave residues in the aquatic environment, increasing the rates of antibiotic resistance in the environment with the potential to transfer resistance gene to human pathogens. ${ }^{118}$ Temperature resistance is also seen among bacteria exposed to a changing and warming environment, and studies suggest that, due 
to similar mechanisms of resistance such as biofilm formation, temperature and antibiotic stress on bacteria can cause a sort of cross resistance. ${ }^{118}$

In a US study of three common Gram negative and Gram positive bacterial pathogens, Escherichia coli, Klebsiella pneumoniae, and Staphylococcus aureus, the authors investigated the relationship between antibiotic resistance and local temperature and other local characteristics. $^{120}$ The study used a data set of over 1.6 million infections and compared regional antibiotic resistance to local geography and climate. ${ }^{120}$ The authors found a significant association between antimicrobial resistance patterns and increasing minimum temperatures and, expectedly, with increased antibiotic prescribing. ${ }^{120}$ They did not, however, find a correlation between antibiotic prescribed and minimum temperature. ${ }^{120}$ Although causality could not be inferred, warmer temperatures are known to increase bacterial growth and horizontal gene transfer, two factors that at least make the contribution of climate to antimicrobial resistance biologically plausible. ${ }^{120-123}$ Other indirect effects of warming on antibiotic resistance have also been demonstrated. ${ }^{119}$ Human bacterial infection rates have been correlated with increasing temperature for reasons probably related to increased pathogen burden in the environment, an increasing number of extreme weather events, as well as changing human behavior due to both short-term weather and long-term climate effects (Burnham). These factors all play a role in increased exposure to potential antibiotic resistant pathogens in the environment as well as in increased antibiotic prescribing. ${ }^{119}$

\section{Conclusion - Potential Threats and Outlook}

We have outlined a few of the infectious diseases and infectious disease risks associated with a changing climate including expanding geographic distribution of pathogen, overcrowding and poor sanitation during extreme weather events, and evolving bacterial resistance patterns. Delayed and missed diagnoses of non-environmental communicable diseases have also been more than a theoretical threat in extreme circumstances. A study of gonorrhea infection among high school students in New Orleans before and after Hurricane Katrina found a doubling of the infection rate before and after the hurricane. ${ }^{124}$ Similarly, when Hurricane Sandy struck the East Coast of the US in 2012, it also resulted in a decrease in HIV screening of up to
$25 \%$ percent in certain areas. This is estimated to have caused thousands of missed testing opportunities. ${ }^{124,125}$

It is also imperative to acknowledge the contribution of the health-care sector to climate change itself. It is estimated that the health-care sector is responsible for about $5 \%$ of global greenhouse gas emissions, and about $10 \%$ of domestic emissions within the United States, primarily driven by fossil fuel combustion and indirect emissions related to the production, transportation, and consumption of pharmaceuticals, medical devices, food and other supplies. ${ }^{126}$ This occurs while simultaneously caring for individuals who become sick with climate change-related diseases. Despite this, peer-reviewed literature examining climate change and health continue to lag behind those relating climate change to other sectors such as transportation, engineering, economics, and energy. This is an area that needs increased focus from sustainability initiatives as well as infection treatment and prevention perspectives.

In conclusion, a potential increase in infectious diseases is a newly recognized consequence of climate change and extreme weather events. Together the phenomena can cause changes in skin microbiome, soil and atmospheric ecology, vector and host geographic range, human displacement and sanitation, antimicrobial resistance patterns, as well as in routine healthcare. Awareness of how the effects of climate change influence infectious disease can help members of the healthcare profession recognize and prepare for both quantitative and qualitative changes in pathogens and infectious disease patterns. While the health-care sector should work toward climate mitigation strategies, climate adaptation is increasingly important among health-care practitioners as climate change and its health consequences become inevitable. The distribution of acceptable habitats for vectors are changing in complexity with global climate change, as are the ways in which people and animals are interacting and migrating. The disruption of once predictable systems will make conducting climate epidemiology more challenging and will require an adaptive conceptual approach.

\section{Author Contributions}

All authors made significant contributions to the work, have drafted, written, or substantially revised or critically reviewed the article, have agreed to the journal of submission, have reviewed and agreed on all versions of the 
article, and agree to take responsibility and be accountable for the contents of the article.

\section{Funding}

Dr. Kobziar's contribution was supported by a W. M. Keck Foundation Grant.

\section{Disclosure}

The authors have no competing interests to declare.

\section{References}

1. US GCRP. The Impacts of Climate Change on Human Health in the United States: A Scientific Assessment. Washington, DC: U.S. Global Change Research Program; 2016.

2. Watts N, Amann M, Arnell N, et al. The 2020 report of the lancet countdown on health and climate change: responding to converging crises. Lancet. 2021;397(10269):129-170. doi:10.1016/ S0140-6736(20)32290-X

3. Bressler RD. The mortality cost of carbon. Nat Commun. 2021;12 (1):4467. doi:10.1038/s41467-021-24487-w

4. Meehl GA, Stocker TF, Collins WD, et al. Global Climate Projections. Chapter. 2007;10:1254.

5. US GCRP. Impacts, Risks, and Adaptation in the United States: Fourth National Climate Assessment, Volume Ii: Report-In-Brief. Washington, DC, USA: U.S. Global Change Research Program; 2018.

6. Rogelj J, Popp A, Calvin KV, et al. Scenarios towards limiting global mean temperature increase below $1.5^{\circ} \mathrm{C}$. Nat Clim Chang. 2018;8(4):325-332. doi:10.1038/s41558-018-0091-3

7. Monaghan AJ, Sampson KM, Steinhoff DF, et al. The potential impacts of 21 st century climatic and population changes on human exposure to the virus vector mosquito Aedes Aegypti. Clim Change. 2016;146(3-4):487-500. doi:10.1007/s10584-0161679-0

8. Verner G, Schütte S, Knop J, Sankoh O, Sauerborn R. Health in climate change research from 1990 to 2014: positive trend, but still underperforming. Glob Health Action. 2016;9(1):30723. doi:10.3402/gha.v9.30723

9. Smith K, Woodward A, Campbell-Lendrum D, et al. Human Health: impacts, Adaptation, and Co-Benefits. Climate Change 2014: Impacts, Adaptation, and Vulnerability. Part A: Global and Sectoral Aspects. Contribution of Working Group Ii to the Fifth Assessment Report of the Intergovernmental Panel on Climate Change. Cambridge University Press; 2014:709-754.

10. Castillo F, Mora AM, Kayser GL, et al. Environmental health threats to Latino migrant farmworkers. Annu Rev Public Health. 2021;42 (1):257-276. doi:10.1146/annurev-publhealth-012420-105014

11. Riden HE, Giacinto R, Wadsworth G, Rainwater J, Andrews T, Pinkerton KE. Wildfire smoke exposure: awareness and safety responses in the agricultural workplace. J Agromedicine. 2020;25 (3):330-338. doi:10.1080/1059924X.2020.1725699

12. Friel S, Schram A, Townsend B. The nexus between international trade, food systems, malnutrition and climate change. Nature Food. 2020;1(1):51-58. doi:10.1038/s43016-019-0014-0

13. Mahapatra B, Walia M, Rao CAR, Raju BMK, Saggurti N. Vulnerability of agriculture to climate change increases the risk of child malnutrition: evidence from a large-scale observational study in India. PLoS One. 2021;16(6):e0253637. doi:10.1371/ journal.pone. 0253637
14. Berry HL, Waite TD, Dear KBG, Capon AG, Murray V. The case for systems thinking about climate change and mental health. Nat Clim Chang. 2018;8(4):282-290. doi:10.1038/s41558-018-0102-4

15. Cianconi $P$, Betrò $S$, Janiri L. The impact of climate change on mental health: a systematic descriptive review. Front Psychiatry. 2020;11:74. doi:10.3389/fpsyt.2020.00074

16. Vicedo-Cabrera AM, Scovronick N, Sera F, et al. The burden of heat-related mortality attributable to recent human-induced climate change. Nat Clim Chang. 2021;11(6):492-500. doi:10.1038/ s41558-021-01058-x

17. Anderson BG, Bell ML. Weather-related mortality: how heat, cold, and heat waves affect mortality in the United States. Epidemiology. 2009;20(2):205-213. doi:10.1097/EDE.0b013e31 8190ee 08

18. Limaye VS, Vargo J, Harkey M, Holloway T, Patz JA. Climate change and heat-related excess mortality in the eastern USA. EcoHealth. 2018;15(3):485-496. doi:10.1007/s10393-018-1363-0

19. Vaidyanathan A, Malilay J, Schramm P, Saha S. Heat-related deaths-United States, 2004-2018. Morbidity Mortality Weekly Rep. 2020;69(24):729. doi:10.15585/mmwr.mm6924a1

20. Santos-Lozada AR, Howard JT. Use of death counts from vital statistics to calculate excess deaths in Puerto Rico following hurricane Maria. JAMA. 2018;320(14):1491-1493. doi:10.1001/ jama.2018.10929

21. Woodward AJ, Samet JM. Climate Change, Hurricanes, and Health. American Public Health Association; 2018.

22. Zakrison TL, Valdés DM, Shultz JM. The medical, public health, and emergency response to the impact of 2017 hurricane Irma in Cuba. Disaster Med Public Health Prep. 2020;14(1):10-17. doi:10.1017/dmp.2019.71

23. Ramesh B, Jagger MA, Zaitchik B, et al. Emergency department visits associated with satellite observed flooding during and following hurricane Harvey. J Expo Sci Environ Epidemiol. 2021;31 (5):832-841. doi:10.1038/s41370-021-00361-1

24. $\mathrm{Xu} \mathrm{R}, \mathrm{Yu} \mathrm{P}$, Abramson MJ, et al. Wildfires, global climate change, and human health. $N$ Engl J Med. 2020;383 (22):2173-2181. doi:10.1056/NEJMsr2028985

25. Finlay SE, Moffat A, Gazzard R, Baker D, Murray V. Health impacts of wildfires. PLoS Curr. 2012;1:4.

26. Sorensen C, House JA, O'Dell K, et al. Associations between wildfire-related Pm2. 5 and intensive care unit admissions in the United States, 2006-2015. GeoHealth. 2021;5(5):e2021GH 000385. doi: 10.1029/2021GH000385

27. Zhang W, Sheridan SC, Birkhead GS, et al. Power outage: an ignored risk factor for COPD exacerbations. Chest. 2020;158 (6):2346-2357. doi:10.1016/j.chest.2020.05.555

28. Tumin R. Winter weather has disrupted hundreds of thousands of Us vaccinations. New York City, NY: New York Times; 2021.

29. Huntjens P, Nachbar K. Climate change as a threat multiplier for human disaster and conflict. Hague Inst Global Justice. 2015;1:548.

30. Gorris ME, Treseder KK, Zender CS, Randerson JT. Expansion of Coccidioidomycosis endemic regions in the United States in response to climate change. GeoHealth. 2019;3(10):308-327. doi:10.1029/2019GH000209

31. Nnadi NE, Carter DA. Climate change and the emergence of fungal pathogens. PLoS Pathog. 2021;17(4):e1009503. doi:10. 1371/journal.ppat.1009503

32. Hoberg EP, Brooks DR. Evolution in action: climate change, biodiversity dynamics and emerging infectious disease. Philosophical Trans Royal Soc B. 2015;370(1665):20130553. doi:10.1098/rstb.2013.0553

33. Beard CB, Eisen RJ, Barker CM, et al. Ch. 5: vectorborne diseases. The Impacts of Climate Change on Human Health in the United States: A Scientific Assessment. Washington, DC: U.S. Global Change Research Program; 2016:129-156. 
34. UCAR Center for Science Education. Climate change: regional impacts. UCAR; 2021. Available from: https://scied.ucar.edu/learn ing-zone/climate-change-impacts/regional. Accessed July 15, 2021.

35. Palazzi E, Mortarini L, Terzago S, von Hardenberg J. Elevationdependent warming in global climate model simulations at high spatial resolution. Climate Dynamics. 2019;52(5):2685-2702. doi:10.1007/s00382-018-4287-z

36. Nielsen-Gammon JW, Zhang F, Odins AM, Myoung B. Extreme rainfall in Texas: patterns and predictability. Phys Geography. 2005;26(5):340-364. doi:10.2747/0272-3646.26.5.340

37. Risser MD, Wehner MF. Attributable human-induced changes in the likelihood and magnitude of the observed extreme precipitation during hurricane Harvey. Geophys Res Lett. 2017;44 (24):12,457-412,464. doi:10.1002/2017GL075888

38. Emanuel K. Assessing the present and future probability of hurricane Harvey's rainfall. Proc National Acad Sci. 2017;114 (48):12681. doi:10.1073/pnas.1716222114

39. Smith A. U.S. Billion-Dollar Weather and Climate Disasters in Historical Context. NCEI/NOAA; 2021.

40. Muhling BA, Jacobs J, Stock Ca, Gaitan CF, Saba VS. Projections of the future occurrence, distribution, and seasonality of three vibrio species in the Chesapeake Bay under a high-emission climate change scenario. GeoHealth. 2017;1 (7):278-296. doi:10.1002/2017GH000089

41. Davis BJK, Corrigan AE, Sun Z, et al. Analysis of traceback investigations for Vibrio Parahaemolyticus Infections (Vibriosis) and pre-harvest environmental conditions in Washington State, 2013-2018. Sci Total Environ. 2021;752:141650. doi:10.1016/j. scitotenv.2020.141650

42. Escobar LE, Ryan SJ, Stewart-Ibarra AM, et al. A global map of suitability for coastal Vibrio Cholerae under current and future climate conditions. Acta Trop. 2015;149:202-211. doi:10.1016/j. actatropica.2015.05.028

43. Randa Mark A, Polz Martin F, Lim E. Effects of temperature and salinity on Vibrio Vulnificus population dynamics as assessed by quantitative PCR. Appl Environ Microbiol. 2004;70 (9):5469-5476. doi:10.1128/AEM.70.9.5469-5476.2004

44. Hackbusch S, Wichels A, Gimenez L, Döpke H, Gerdts G. Potentially human pathogenic vibrio spp. in a coastal transect: occurrence and multiple virulence factors. Sci Total Environ. 2020;707:136113. doi:10.1016/j.scitotenv.2019.136113

45. Logar-Henderson C, Ling R, Tuite AR, Fisman DN. Effects of large-scale oceanic phenomena on non-cholera vibriosis incidence in the United States: implications for climate change. Epidemiol Infect. 2019;147:e243-e243. doi:10.1017/S0950268819001316

46. Janda JM, Newton AE, Bopp CA. Vibriosis. Clin Lab Med. 2015;35(2):273-288. doi:10.1016/j.cll.2015.02.007

47. Dechet AM, Yu PA, Koram N, Painter J. Nonfoodborne vibrio infections: an important cause of morbidity and mortality in the United States, 1997-2006. Clin Infect Dis. 2008;46(7):970-976. doi: $10.1086 / 529148$

48. Ralston EP, Kite-Powell H, Beet A. An estimate of the cost of acute health effects from food- and water-borne marine pathogens and toxins in the USA. J Water Health. 2011;9(4):680-694. doi:10.2166/wh.2011.157

49. Weis KE, Hammond RM, Hutchinson R, Blackmore CGM. Vibrio illness in Florida, 1998-2007. Epidemiol Infect. 2011;139 (4):591-598. doi:10.1017/S0950268810001354

50. Newton A, Kendall M, Vugia DJ, Henao OL, Mahon BE. Increasing rates of vibriosis in the United States, 1996-2010: review of surveillance data from 2 systems. Clin Infect Dis. 2012;54(5):S391-S395. doi:10.1093/cid/cis243

51. Jones EH, Feldman KA, Palmer A, Butler E, Blythe D, Mitchell CS. Vibrio infections and surveillance in Maryland, 2002-2008. Public Health Rep. 2013;128(6):537-545. doi:10. $1177 / 003335491312800613$
52. Yoder JS, Eddy BA, Visvesvara GS, Capewell L, Beach MJ. The epidemiology of primary amoebic Meningoencephalitis in the USA, 1962-2008. Epidemiol Infect. 2010;138(7):968-975. doi:10.1017/S0950268809991014

53. Capewell LG, Harris AM, Yoder JS, et al. Diagnosis, clinical course, and treatment of primary amoebic Meningoencephalitis in the United States, 1937-2013. J Pediatric Infect Dis Soc. 2015;4(4):e68-e75. doi:10.1093/jpids/piu103

54. Gharpure R, Gleason M, Salah Z, et al. Geographic range of recreational water-associated primary amebic Meningoencephalitis, United States, 1978-2018. Emerg Infect Dis. 2021;27(1):271-274. doi:10.3201/eid2701.202119

55. Mwachui MA, Crump L, Hartskeerl R, Zinsstag J, Hattendorf J. Environmental and behavioural determinants of leptospirosis transmission: a systematic review. PLoS Negl Trop Dis. 2015;9 (9):e0003843. doi:10.1371/journal.pntd.0003843

56. Costa F, Hagan JE, Calcagno J, et al. Global morbidity and mortality of leptospirosis: a systematic review. PLoS Negl Trop Dis. 2015;9(9):e0003898. doi:10.1371/journal.pntd.0003898

57. Naing C, Reid SA, Aye SN, Htet NH, Ambu S. Risk factors for human leptospirosis following flooding: a meta-analysis of observational studies. PLoS One. 2019;14(5):e0217643. doi:10.1371/ journal.pone.0217643

58. Gaynor K, Katz AR, Park SY, Nakata M, Clark TA, Effler PV. Leptospirosis on Oahu: an outbreak associated with flooding of a university campus. Am J Trop Med Hyg. 2007;76(5):882-886. doi:10.4269/ajtmh.2007.76.882

59. Department of Health. Leptospirosis. Department of Health; 2021.

60. Katz AR, Sasaki DM, Mumm AH, Escamilla J, Middleton CR, Romero SE. Leptospirosis on Oahu: an outbreak among military personnel associated with recreational exposure. Mil Med. 1997;162(2):101-104. doi:10.1093/milmed/162.2.101

61. Amilasan A-ST, Ujiie M, Suzuki M, et al. Outbreak of Leptospirosis after Flood, the Philippines, 2009. Emerg Infect Dis. 2012;18(1):91-94. doi:10.3201/eid1801.101892

62. Lau CL, Smythe LD, Craig SB, Weinstein P. Climate Change, Flooding, Urbanisation and Leptospirosis: fuelling the Fire? Trans $R$ Soc Trop Med Hyg. 2010;104(10):631-638. doi:10.1016/j.trstmh.2010.07.002

63. Timmusk S, Nevo E, Ayele F, Noe S, Niinemets Y. Fighting Fusarium Pathogens in the Era of Climate Change: a Conceptual Approach. Pathogens. 2020;9(6):419. doi:10.3390/ pathogens 9060419

64. Ortoneda M, Guarro J, Madrid Marta P, et al. Fusarium Oxysporum as a Multihost Model for the Genetic Dissection of Fungal Virulence in Plants and Mammals. Infect Immun. 2004;72 (3):1760-1766. doi:10.1128/IAI.72.3.1760-1766.2004

65. Bertero A, Moretti A, Spicer LJ, Caloni F. Fusarium Molds and Mycotoxins: potential Species-Specific Effects. Toxins. 2018;10 (6):244. doi:10.3390/toxins 10060244

66. Wurster S, Tatara Alexander M, Albert Nathaniel D, et al. Tornadic Shear Stress Induces a Transient, Calcineurin-Dependent Hypervirulent Phenotype in Mucorales Molds. mBio. 2020;11(3): e01414-01420. doi:10.1128/mBio.01414-20

67. Uejio CK, Mak S, Manangan A, Luber G, Bartlett KH. Climatic Influences on Cryptococcus Gattii Populations, Vancouver Island, Canada, 2002-2004. Emerg Infect Dis. 2015;21(11):1989. doi:10. 3201/eid2111.141161

68. Hoang LMN, Maguire JA, Doyle P, Fyfe M, Roscoe DL. Cryptococcus Neoformans Infections at Vancouver Hospital and Health Sciences Centre (1997 2002): epidemiology, Microbiology and Histopathology. J Med Microbiol. 2004;53(9):935-940. doi:10.1099/jmm.0.05427-0

69. Lester SJ, Malik R, Bartlett KH, Duncan CG. Cryptococcosis: update and Emergence of Cryptococcus Gattii. Veterinary Clin Pathol. 2011;40(1):4-17. doi:10.1111/j.1939-165X.2010.00281.x 
70. Diaz JH. The Disease Ecology, Epidemiology, Clinical Manifestations, and Management of Emerging Cryptococcus Gattii Complex Infections. Wilderness Environ Med. 2020;31 (1):101-109. doi:10.1016/j.wem.2019.10.004

71. Kidd SE, Chow Y, Mak S, et al. Characterization of Environmental Sources of the Human and Animal Pathogen Cryptococcus Gattii in British Columbia, Canada, and the Pacific Northwest of the United States. Appl Environ Microbiol. 2007;73(5):1433-1443. doi:10.1128/AEM.01330-06

72. Centers for Disease Control and Prevention. Emergence of Cryptococcus Gattii-Pacific Northwest, 2004-2010. MMWR Morb Mortal Wkly Rep. 2010;59(28):865-868.

73. Rosas ÁL, Casadevall A. Melanization Affects Susceptibility of Cryptococcus Neoformans to Heat and Cold. FEMS Microbiol Lett. 1997;153(2):265-272. doi:10.1016/S0378-1097(97)00239-5

74. Wang Y, Casadevall A. Decreased Susceptibility of Melanized Cryptococcus Neoformans to UV Light. Appl Environ Microbiol. 1994;60(10):3864-3866. doi:10.1128/aem.60.10.3864-3866.1994

75. Schiave LA, Pedroso RS, Candido RC, Roberts DW, Braga GUL. Variability in UVB Tolerances of Melanized and Nonmelanized Cells of Cryptococcus Neoformans and C. laurentii. Photochem Photobiol. 2009;85(1):205-213. doi:10.1111/j.1751-1097.2008.00 418.x

76. Jackson BR, Chow N, Forsberg K, et al. On the Origins of a Species: what Might Explain the Rise of Candida Auris? J Fungi. 2019;5(3):58. doi:10.3390/jof5030058

77. Chase AB, Weihe C, Martiny JBH. Adaptive Differentiation and Rapid Evolution of a Soil Bacterium Along a Climate Gradient. Proc National Acad Sci. 2021;118(18):e2101254118. doi:10. 1073/pnas.2101254118

78. Fann N, Brennan T, Dolwick P, et al. Ch. 3: air Quality Impacts. The Impacts of Climate Change on Human Health in the United States: A Scientific Assessment. Washington, DC: U.S. Global Change Research Program; 2016:69-98.

79. Bell JE, Herring SC, Jantarasami L, et al. Ch. 4: impacts of Extreme Events on Human Health. The Impacts of Climate Change on Human Health in the United States: A Scientific Assessment. Washington, DC: U.S. Global Change Research Program; 2016:99-128.

80. Kobziar LN, Thompson GR. Wildfire smoke, a potential infectious agent. Science. 2020;370(6523):1408-1410. doi:10.1126/ science.abe 8116

81. Fear VS, Boyd JH, Rea S, Wood FM, Duke JM, Fear MW. Burn Injury Leads to Increased Long-Term Susceptibility to Respiratory Infection in Both Mouse Models and Population Studies. PLoS One. 2017;12(1):e0169302-e0169302. doi:10.13 71/journal.pone.0169302

82. Palmieri TL. Infection prevention: unique aspects of burn units. Surg Infect (Larchmt). 2019;20(2):111-114. doi:10.1089/ sur.2018.301

83. Strassle PD, Williams FN, Weber DJ, et al. Risk factors for healthcare-associated infections in adult burn patients. Infect Control Hospital Epidemiol. 2017;38(12):1441-1448. doi:10.10 17/ice. 2017.220

84. Sobouti B, Dahmardehei M, Fallah S, Karrobi M, Ghavami Y, Vaghardoost R. Candidemia in Pediatric Burn Patients: risk Factors and Outcomes in a Retrospective Cohort Study. Curr Med Mycol. 2020;6(3):33. doi:10.18502/cmm.6.3.4663

85. Capoor MR, Sarabahi S, Tiwari VK, Narayanan RP. Fungal infections in burns: diagnosis and management. Indian J Plastic Surg. 2010;43(S 01):S37-S42. doi:10.4103/09700358.70718

86. Kobziar LN, Pingree MRA, Larson H, Dreaden TJ, Green S, Smith JA. Pyroaerobiology: the aerosolization and transport of viable microbial life by wildland fire. Ecosphere. 2018;9(11): e02507. doi:10.1002/ecs2.2507
87. Moore RA, Bomar C, Kobziar LN, Christner BC. Wildland Fire as an Atmospheric Source of Viable Microbial Aerosols and Biological Ice Nucleating Particles. ISME J. 2021;15(2): 461-472. doi:10.1038/s41396-020-00788-8

88. Mulliken JSRA, Fung M, Babik JM, Doernberg SB Is Exposure to Wildfires Associated with Invasive Fungal Infections? [Abstract]. Paper presented at: American Transplant Congress; 2019.

89. Kobziar LN. Potential Pathogens Identified in Wildland Fire Smoke. Hauser N, ed; 2021

90. Elbert W, Taylor PE, Andreae MO, Pöschl U. Contribution of Fungi to Primary Biogenic Aerosols in the Atmosphere: wet and Dry Discharged Spores, Carbohydrates, and Inorganic Ions. Atmospheric Chem Phys. 2007;7(17):4569-4588. doi:10.5194/ acp-7-4569-2007

91. Sherry NL, Padiglione AA, Spelman DW, Cleland H. Microbiology of Wildfire Victims Differs Significantly from Routine Burns Patients: data from an Australian Wildfire Disaster. Burns. 2013;39(2):331-334. doi:10.1016/j.burns.2012. 07.017

92. Biesiada G, Czepiel J, Leśniak MR, Garlicki A, Mach T. Lyme disease: review. Arch Med Sci. 2012;8(6):978-982. doi:10.5114/ aoms.2012.30948

93. Estrada-Peña A, Ayllón N, de la Fuente J. Impact of climate trends on tick-borne pathogen transmission. Front Physiol. 2012;3:64. doi:10.3389/fphys.2012.00064

94. Ogden NH, Lindsay LR. Effects of climate and climate change on vectors and vector-borne diseases: ticks are different. Trends Parasitol. 2016;32(8):646-656. doi:10.1016/j.pt.2016.04.015

95. Ogden Nicholas H, Radojevic' M, Wu X, Duvvuri Venkata R, Leighton Patrick A, Wu J. Estimated Effects of Projected Climate Change on the Basic Reproductive Number of the Lyme Disease Vector Ixodes Scapularis. Environ Health Perspect. 2014;122 (6):631-638. doi:10.1289/ehp.1307799

96. Leighton PA, Koffi JK, Pelcat Y, Lindsay LR, Ogden NH. Predicting the Speed of Tick Invasion: an Empirical Model of Range Expansion for the Lyme Disease Vector Ixodes Scapularis in Canada. J App Ecol. 2012;49(2):457-464. doi:10.1111/j.13652664.2012.02112.x

97. Simon JA, Marrotte RR, Desrosiers N, et al. Climate Change and Habitat Fragmentation Drive the Occurrence of Borrelia Burgdorferi, the Agent of Lyme Disease, at the Northeastern Limit of Its Distribution. Evol Appl. 2014;7(7):750-764. doi:10.1111/eva.12165

98. Roy-Dufresne E, Logan T, Simon JA, Chmura GL, Millien V. Poleward Expansion of the White-Footed Mouse (Peromyscus Leucopus) under Climate Change: implications for the Spread of Lyme Disease. PLoS One. 2013;8(11):e80724-e80724. doi:10.1371/journal.pone.0080724

99. Rounsville TF, Dill GM, Bryant AM, Desjardins CC, Dill JF. Statewide Passive Surveillance of Ixodes Scapularis and Associated Pathogens in Maine. Vector Borne Zoonotic Dis. 2021;21(6):406-412. doi:10.1089/vbz.2020.2724

100. Boorgula GDY, Peterson AT, Foley DH, Ganta RR, Raghavan RK. Assessing the Current and Future Potential Geographic Distribution of the American Dog Tick, Dermacentor Variabilis (Say)(Acari: Ixodidae) in North America. PLoS One. 2020;15(8):e237191. doi:10.1371/journal.pone.0237191

101. Pascoe EL, Plourde BT, Lopéz-Perez AM, Foley JE. Response of small mammal and tick communities to a catastrophic wildfire and implications for tick-borne pathogens. $J$ Vector Ecol. 2020;45 (2):269-284. doi:10.1111/jvec. 12398

102. Pastula DM, Smith DE, Beckham JD, Tyler KL. Four Emerging Arboviral Diseases in North America: Jamestown Canyon, Powassan, Chikungunya, and Zika Virus Diseases. J Neurovirol. 2016;22(3):257-260. doi:10.1007/s13365-016-0428-5 
103. Ronca SE, Ruff JC, Murray KO. A 20-Year Historical Review of West Nile Virus since Its Initial Emergence in North America: has West Nile Virus Become a Neglected Tropical Disease? PLoS Negl Trop Dis. 2021;15(5):e0009190. doi:10.1371/journal.pntd.0009190

104. IDMC. Global Report on Internal Displacement. Geneva, Switzerland: Internal Displacement Monitoring Centre; 2020.

105. McMichael C. Climate change-related migration and infectious disease. Virulence. 2015;6(6):548-553. doi:10.1080/21505594. 2015.1021539

106. Black R. Environmental Refugees: myth or Reality? United Nations High Commissioner for Refugees. New issues in refugee research, working paper 34; 2001.

107. Brown O. Climate Change and Forced Migration: Observations, Projections and Implications. Human Development Report Office (HDRO), United Nations Development Programme; 2007.

108. Freeman L. Environmental change, migration, and conflict in Africa: a critical examination of the interconnections. J Environ Dev. 2017;26(4):351-374. doi:10.1177/1070496517727325

109. King D, Bird D, Haynes K, et al. Voluntary relocation as an adaptation strategy to extreme weather events. Int $J$ Disaster Risk Reduction. 2014;8:83-90. doi:10.1016/j.ijdrr.2014.02.006

110. Schütte S, Gemenne F, Zaman M, Flahault A, Depoux A. Connecting planetary health, climate change, and migration. Lancet Planetary Health. 2018;2(2):e58-e59. doi:10.1016/ S2542-5196(18)30004-4

111. Raleigh C, Jordan L. Assessing the Impact of Climate Change on Migration and Conflict. Washington, DC: Inpaper commissioned by the World Bank Group for the Social Dimensions of Climate Change workshop; 2008.

112. Feng S, Krueger AB, Oppenheimer M. Linkages among Climate Change, Crop Yields and Mexico-Us Cross-Border Migration. Proc National Acad Sci. 2010;107(32):14257. doi:10.1073/ pnas. 1002632107

113. Steffens G. Changing Climate Forces Desperate Guatemalans to Migrate. National Geographic; 2018. Available from: https://www. nationalgeographic.com/environment/article/drought-climatechange-force-guatemalans-migrate-to-us. Accessed July 30, 2021.

114. UNHCR. Climate Change and Disaster Displacement. UN Refugee Agency; 2021.

115. McMichael AJ. Globalization, climate change, and human health. $N$ Engl J Med. 2013;368(14):1335-1343. doi:10.1056/NEJMra 1109341

116. Yee EL, Palacio H, Atmar RL, et al. Widespread Outbreak of Norovirus Gastroenteritis among Evacuees of Hurricane Katrina Residing in a Large "Megashelter" in Houston, Texas: lessons Learned for Prevention. Clin Infect Dis. 2007;44(8):1032-1039. doi:10.1086/512195
117. Dayrit JF, Sugiharto A, Coates SJ, Lucero-Prisno DE, Davis MDD, Andersen LK. Climate Change, Human Migration, and Skin Disease: is There a Link? Int J Dermatol. 2021. doi:10.1111/ijd.15543

118. Pepi M, Focardi S. Antibiotic-Resistant Bacteria in Aquaculture and Climate Change: a Challenge for Health in the Mediterranean Area. Int $J$ Environ Res Public Health. 2021;18(11):5723. doi:10.3390/ijerph18115723

119. Burnham JP. Climate change and antibiotic resistance: a deadly combination. Ther Adv Infect Dis. 2021;8:2049936121991374. doi:10.1177/2049936121991374

120. MacFadden DR, McGough SF, Fisman D, Santillana M, Brownstein JS. Antibiotic resistance increases with local temperature. Nat Clim Chang. 2018;8(6):510-514. doi:10.1038/ s41558-018-0161-6

121. Lorenz MG, Wackernagel W. Bacterial gene transfer by natural genetic transformation in the environment. Microbiol Rev. 1994;58(3):563-602. doi:10.1128/mr.58.3.563-602.1994

122. Walsh TR, Weeks J, Livermore DM, Toleman MA. Dissemination of Ndm-1 Positive Bacteria in the New Delhi Environment and Its Implications for Human Health: an Environmental Point Prevalence Study. Lancet Infect Dis. 2011;11(5):355-362. doi:10. 1016/S1473-3099(11)70059-7

123. Shah HN, Gharbia SE. The impact of the environment on human infections. Microb Ecol Health Dis. 1999;11(4):248-254. doi:10. 1080/08910609908540835

124. Nsuami MJ, Taylor SN, Smith BS, Martin DH. Increases in gonorrhea among high school students following hurricane Katrina. Sex Transm Infect. 2009;85(3):194. doi:10.1136/sti.20 08.031781

125. Ekperi LI, Thomas E, LeBlanc TT, et al. The impact of hurricane Sandy on HIV testing rates: an interrupted time series analysis, January 1, 2011-December 31, 2013. PLoS Curr. 2018; 10 .

doi:10.1371/currents.dis. ea09f9573dc292951b7eb0cf9f395003

126. Eckelman MJ, Huang K, Lagasse R, Senay E, Dubrow R, Sherman JD. Health care pollution and public health damage in the United States: an update. Health Aff. 2020;39(12):2071-2079. doi:10.1377/hlthaff.2020.01247

127. NOAA, Climate.gov. Available from https://www.climate.gov/ media/12884. Accessed December 12, 202
Infection and Drug Resistance

\section{Publish your work in this journal}

Infection and Drug Resistance is an international, peer-reviewed openaccess journal that focuses on the optimal treatment of infection (bacterial, fungal and viral) and the development and institution of preventive strategies to minimize the development and spread of resistance. The journal is specifically concerned with the epidemiology of antibiotic resistance and the mechanisms of resistance development and diffusion in both hospitals and the community. The manuscript management system is completely online and includes a very quick and fair peerreview system, which is all easy to use. Visit http://www.dovepress.com/ testimonials.php to read real quotes from published authors. 